\title{
Biology Teacher Training: Metacognitive Analysis to Praxis Reflection
}

\author{
Rafael Santos de Aquino \\ Federal Institute of Sertão Pernambucano \\ - IF SERTÃO-PE, Brazil
}

\author{
Ana M. A. Carneiro-Leão \\ Federal Rural University of Pernambuco - \\ UFRPE, Brazil
}

\begin{abstract}
In order to analyze the formation of concepts of the specific content in Biochemistry, under the theme of Application of Biochemistry in Animal Nutrition, during the training in Full Degree in Biological Sciences of a acting teacher, a comparative analysis was performed between the first and the last discipline plans and lessons plans and two conceptual maps, being one in the 3rd period and another in the 8th period of the Biology Licenciatura course. The analysis made it possible to perceive the influence of undergraduate education applied to teacher training in the development of a systemic-complex thinking, in the consideration of reflexive action in teaching practice and the historical and socio-cultural influence present in the productions that reflect the moment of the author.
\end{abstract}

\section{Introduction}

This work presents a metacognitive proposal for the analysis of the Biology teacher training process from the life history itself, considering the knowledge and the experiences acquired.

In order to do so, our work is methodologically situated in metacognition, in a process of selfreflection during teacher training, which gives importance to references such as Shulman and Tardiff, having as an analytical way the construction of concepts in Biochemistry.

Throughout the undergraduate course, called in Brazil of Licenciatura ${ }^{1}$, the student in the process of teacher training is exposed to different knowledge through the different disciplines that are complemented in a macro context generating a series of constructions and reconstructions of the knowledge by the relations between the contents and the studied areas.

Some teachers' training theorists such as Shulman [14] and Tardiff [15] argue that the teacher throughout his initial and ongoing formation process exercises the reflection of his praxis as self-assessment. This reflexive act can be made supported by the

\footnotetext{
${ }^{1}$ A Licenciatura course in Brazil is an undergraduate course aimed at the training of teachers in the fields of biology, mathematics, literature, history, etc., where are distinguished courses of Licenciatura and Bachelor's degree. For example, the Bachelor of
}

metacognitive theory that provides self-knowledge through self-assessment [8].

The aim of this work was to understand the importance of the Biology degree course applied to the Biology teacher training, in a student who already works as a teacher, through the metacognitive analyzing of the evolution of the pedagogical knowledge linked to the didactic planning and also in relation to the development of specific knowledge in a comparison between the start and the end of the course.

This situational amalgam specifically involves the problematization of this work: what is the influence of the undergraduate course in Biological Sciences in the pedagogical skills and the formation of concepts in Biochemistry from the metacognitive analysis of a student? In order to understand this problematization, we need to focus a little on the principles of teacher training, construction of concepts and metacognition.

\section{Consideration for teacher training}

The goals of teaching are numerous and varied, and they also grow in a disorganized manner if we consider the goals of the subjects and the goals of other school services, not to mention the goals of the teachers themselves [18]. Teachers are now increasingly required to become pedagogical professionals who can cope with the numerous challenges posed by schooling at all levels of education [13]. But, for Tardif [18], wanting to study professional knowledge without associating it with a teaching situation, teaching practices and a teacher would be absurd, as well as wanting to study a teacher without studying work and learning. To know them would be even more absurd.

In contrast, Shulman [17] states that while understanding is a central conception of teaching to foster learning, teaching should be more than the enhancement of understanding, so the teacher must know more than make himself understand how to have the following knowledge. From the common sense, that to be a teacher just know some content, argues that being a teacher is much more than that,

Biological Sciences course (for the general market) and the Biological Sciences Licenciatura (for the training of the Biology teacher). 
since if so, all university teachers, researchers and experts in its content should be excellent teachers, and the inefficiency of classroom specialists is one of the biggest complaints from students.

It is natural that prospective teachers have developed a teaching belief system during their experience as elementary and high school students. Formosinho [10] corroborates this when he states that teaching is a profession that is learned in the experience of discourse. Tardif and Raymond [19] state that by evoking desirable or undesirable qualities that he wants to embody or avoid as a teacher; he will remember the outstanding personality of a teacher. Tardif [18] believes that much of what teachers know about teaching, about the teacher's roles, and how to teach, comes from their own life story, and especially from their school life story.

Marcon et al. [14] argues that pedagogical knowledge coupled with specific knowledge will be responsible for distinguishing the student-teacher from higher education, from the student he was before, in Basic Education. But of course, several theorists such as Tardif [18], Shulman [17] and Gauthier [11] argue that teaching knowledge is the result of an amalgam of various types of knowledge that must be managed simultaneously by the teacher.

Lima et al. [13] pay attention to the stigmatized conceptions as that the teaching profession is intrinsically involved with mission, priesthood, love, vocation, etc., under this vocational nature, Tardif [18] states that the teaching work constantly requires investment deep, both from the affective and cognitive point of view in the relations with students, calling this type of work invested or lived, because in this case the teacher can not only do his work, but must also dedicate himself and invest in this work. what he is as a person and that interpersonal knowledge cannot be a gift or vocation if it can be learned

Practitioners should rely on specialized and formalized knowledge, most often through broad scientific disciplines, including of course the natural and applied sciences, but also the social and human sciences as well as the educational sciences [18].

Gauthier [11] conceives teaching as the mobilization of various knowledge that form a kind of reservoir that is used to respond to the demands of concrete teaching situations and classifies such knowledge as: (1) disciplinary, referring to knowledge of content; (2) curriculum, concerning the transformation of the discipline into a teaching program; (3) Educational Sciences, related to specific professional knowledge that is not related to pedagogical action; pedagogical tradition, related to the knowledge of teaching that will be adapted and modified by experiential knowledge, and can be validated by the taste of pedagogical action; (4) experience regarding private judgments responsible for the elaboration, over time, of a particular case law; and (5) pedagogical action, referring to referential knowledge made public and tested. This reservoir exemplified by Gauthier [11], Shulman [17] calls the Pedagogical Content Knowledge (PCK) which represents the teachers' professional knowledge which consists of three categories of teacher content knowledge: content knowledge in question, knowledge of the pedagogical content and knowledge of the curriculum. The PCK as the set of knowledge that distinguishes a teacher of a given subject from a specialist of that same subject. Shulman [17] says that teaching is first to understand, where the teacher must critically understand a set of ideas to be taught. And Tardif [18] points out that a teacher rarely has a theory or a unitary conception of his practice, on the contrary, teachers use many theories, conceptions and techniques as needed.

Gauthier [11] states that the knowledge of professional teachers is temporal, plural and heterogeneous, personalized and situated and carry the marks of the human being. It also states that knowledge related to content, experience and culture is essential to the exercise of teaching activity.

Shulman [17] also highlights the teacher's reflexive act, as a form of learning, because when he looks back at teaching and learns what happened and, rebuilds, re-enacts and / or recaptures events, emotions and achievements, this set of processes responsible for professional learning, experience and can be done alone or together with the help of recording devices or just through memory.

Is essential that the teacher understands education and contextualize it to understand it in its complexity, considering the multiple aspects that involve it, to be understood as an exercise of permanent praxis (action-reflection-action), being Education is exercised in the concrete social context.

The teacher is in a constant process of construction, deconstruction and reconstruction, his identity is always molding from his changes of feelings, values, attitudes, desire, that is, starting from reflection on what kind of professional the teacher wants to be. he changes and goes in search of new learning, to improve what he already knows and to reconsider the relevance and scope of his actions.

\subsection{Consideration for constructing concepts in teacher education}

Learning is due to the cognitive process of concept formation through the language that permeates social relations over time. This historical-cultural influence on communication processes is addressed by Scott [16] in stating that signs are not merely analogous to a visual perception, but symbolic artifacts constructed from cultural conventions.

Farias [6] considering the semiotic structuring of the cognitive process, brings an interrelation with the systemic-complex paradigmatic configuration 
(articulated reprocessing of the parts and with the whole [2]) by promoting the interpretation of descriptive processes from simple interactions of signs to the more complex ones considering the habit as knowledge internalization behavior hindering its loss and substitution or constructive transformation of a knowledge and the dynamic interaction of the cognitive process that constructs and reconstructs a certain knowledge.

Considering social constructivism, we can cite the statement of Marcon et al. [14]:

"[...] the teacher began to be a teacher when he attended school benches, when he was part of the school as a student." Marcon et al. (pp. 778, 2010).

Thus, in over time, the construction of concepts of gave in a continuous, it is natural that future teachers have developed a system of beliefs about teaching during the student experience [14].

Corroborates this when he affirms that teaching is a profession that is learned in the experience of the discourse [9]. Tardif and Raymond [19] argue that by evoking desirable or undesirable qualities that he wants to incarnate or avoid as a teacher he will remember the remarkable personality of a teacher. Much of what teachers know about teaching comes from their own life story [17].

The reflexive act of the teacher, as a way of learning, because when he looks back at teaching and learns what happened and, reconstructs, re-addresses and/or recaptures events, emotions and achievements, being this set of processes responsible for professional learning [18]. In this section, [6] believes that teacher knowledge is constituted by the specialization of knowledge, where knowledge passes through the reflection of know-how, elevating practice to a level of awareness, reflection, analysis, systematization and intention. Thus, it is appropriate to approach conscious, analytical, systematized and intentional reflection as a metacognitive action of great importance for teaching performance in order to promote professional self-development.

Faced with this, we must treat metacognition as an exercise of teaching learning that can be explored from the initial formation of the teacher in undergraduate courses to continuing education when, already graduated, the teacher exercises the reflection on his work practice in a constant process of selfobservation of praxis, his careful self-analysis and self-assessment in order to propose changes aimed at improving teaching practice and consequent learning and improvement of teaching technique.

\subsection{Metacognition as a Teacher Learning Exercise}

Metacognition is a philosophical-cognitive artifice that has long been approached by thinkers, such as Socrates, for example, when he uttered the sentence "I only know that I know nothing" by recognizing his cognitive limitation and by researchers such as Piaget and Vygotsky consciousness and the social origins of cognitive control that propelled the development of the concept of metacognition [20], but was grounded in the 1970s by John Flavell [8], [9] who defined it conceptually and epistemologically.

In 1979, Flavell [8], in his studies on memorization, developed a global model of cognitive monitoring that includes four interrelated aspects: 1) metacognitive knowledge (which brings together the sensitivity and knowledge components of the person, task, and strategy variables); 2) metacognitive experiences; 3) objectives and 4) actions or strategies. Other definitions are presented, for example, as the knowledge that the subject has about knowledge itself and the consequent ability to regulate its executive processes, in addition to the control of these mechanisms [8], [9].

According to Cypel [4] since the 1970s, studies on metacognition have deepened into different models, as can be seen from the highlight brought by Jou and Sperb (2006) when they presented the model developed by Flavell (1987) with the four related structures, cognitive goals and cognitive actions, which interact with each other and with metacognitive experience and metacognitive knowledge; and the functional model of Nelson and Narens (1996), consistent with information processing, which emphasizes two relationships of information flows, monitoring and control, between the cognitive instance or object level and the metacognitive instance, or goal level.

This diversification obtained with the advancement of studies on metacognition has also generated a great diversity of "metacognitive terms" as highlighted by Cypel [4], Lima [13] identifying the following terms: metacognitive beliefs, metacognitive awareness, feeling of knowing, judgment of learning, theory of mind, meta-memory, metacognitive skills, executive skills, high order skills, comprehension monitoring, learning strategies, among others, would be terms associated with metacognition.

Other definitions are presented, for example, as that knowledge that the subject has about his own knowledge and the consequent capacity to regulate its executive processes, added to the control and orchestration of these same mechanisms [8] and [9].

Metacognitions can be considered second-order cognitions: thoughts on thoughts, knowledge on knowledge, reflections on actions. Wolfs [20], in explaining metacognition, defines the principle of cognitive self-regulation and consequent executive control when he claims to be the control of cognition itself as a result of the process of interaction with awareness. This interaction does not always occur, requiring activations that will start with selfknowledge, making the individual initially aware of what he has learned well, what he has not learned well 
and what he has not learned. sometimes changing strategies, that is controlling the execution of the learning process.

However, the wide use of the term metacognition in the psychological literature presents conceptual contradictions, when it refers to the knowledge of one's own knowledge, one's own cognitive processes and their forms of operation as executive control (which involves regulation or cognitive monitoring) in which it has identified isolated approaches from these important points for the definition of metacognition and argues that while different sources and different problems appear, cognition regulation and executive control should be considered together for understanding metacognition.

Cypel [4] characterizes executive functions as a neuropsychological functional system, composed of a set of functions responsible for initiating and developing an activity with a determined objective, resulting in the planning and regulation of behavior. They organize perceptual, mnetic and praxic capacities within a context in order to: elect a goal, decide on the start of the proposal, plan the implementation steps, monitor the steps against the proposed model, modify the model if necessary, evaluate the final result against the initial objective [4].

Executive functions are grouped into four domains: (1) desire or will - anticipation, motivation, intentional behavior; (2) planning - conceptualization, decision making, maintenance, integration and alternation of behavioral sequences, mental flexibility, inhibition, attention control and memory; and monitoring - effective performance control, regulation of qualitative aspects of behavior, use of feedback [4]. The executive functions affect personal and social behavior, since an individual's actions may encourage other people to perform the same action as well.

Paris and Winograd [15] discriminate in metacognition three types of knowledge: 1) Declarative, which is to be aware of what is known and the strategies to be used; 2) Executive, which is the knowledge of how to perform a particular task or apply a strategy; 3) Conditional, that knowledge that provides the decision of when and where to use a particular strategy.

When considering only the learning process, affirmed that metacognition can assume two meanings, the evaluation of resources and metacognition in action [12]. The first meaning refers to the personal reflections on the state of knowledge and cognitive skills, on the characteristics of the tasks and the strategies available to perform the task. The second meaning concerns personal reflections on the organization and planning of the action before the task begins and in the verification of the results.

In this perspective, it is important to understand that thinking involves cognitive abilities such as perception, attention, symbolization, selection, memory, transference, evaluation, etc., whose interaction results in thinking [6] and [10] the same as memorizing, learning is the result of knowing how to learn, which is not enough to do and know, but you have to know how to know.

In view of the arguments presented, our work proposes to analyze the formation of concepts of the specific content of Biochemistry during the training in Biological Sciences course at Licenciatura type using metacognition for the analytical understanding of the conceptual construction on the relation of Biochemistry in Animal Nutrition through of the study and metacognitive self-analysis of a student, comparing correlated productions at the beginning and end of the degree course in Biological Sciences.

\section{Methodology}

This article is the result of the monograph of the Completion of Course Work in Biological Sciences Full Degree of the Federal Rural University of Pernambuco entitled "Teacher-student and studentteacher: teacher training in full teaching" and presented in February 2018.

We should present it as an autobiographical work where the author, who at the time was an activity professor teaching Animal Science and was a student of the Biological Sciences Licenciatura (area related to Animal Science), to learn teaching techniques and to improve the profession of a duly licensed teacher, as required by Brazilian law [3] (Law of Guidelines and Bases of Education - LDB - Law 9.394 of 1996, article 62):

"The training of teachers to work in basic education will be carried out at a higher level, in the course of a full degree, admitted as a minimum training for the exercise of teaching in early childhood education and in the first five years of basic education, offered in average level, in the normal modality. "[3].

We sought scientific-methodological support in Flavell's model of cognitive monitoring [11] and in the author's conceptualization of metacognition when he argues that being the subject's knowledge about his own knowledge and the consequent ability to regulate his executive processes.

In this way Flavell's model of cognitive monitoring could be applied as follows [9]:

1) Cognitive knowledge that encompasses the sensitivity and knowledge of the variables of the person, the task and the strategy: at this stage, reflection and self-criticism were worked out to develop and sharpen the sensibility about one's own qualities and especially about one's limitations as a teacher, seeking to identify the variables that influence such limiting characteristics or not, as well as to deepen the knowledge about the task of teaching and its strategies based on the principles of Tardif and 
Shulman;

2) Cognitive experiences: cognitive experiences can be analyzed in thought materializations through products derived from studies of specific disciplines, in this case, the conceptual maps constructed in the 3rd period of the course in the discipline of Systemic Biochemistry and in the 8 th period on the same thematic to the point of identifying the cognitive differences under the influence of the study of several disciplines along the course added to the own experience in the classroom;

3) Objectives: The mains objectives of this activity of cognitive monitoring on pedagogical content develop (metacognitive analyses between the firsts discipline plan and lessons plan with the lasts ones) and Biochemistry in Animal Nutrition was to comparatively analysis two cognitive moments through the materialization of two Conceptual Maps, one at the beginning and another at the end of the course of Biological Sciences. Analysis that was based on the study of metacognition and the conceptual precepts of the teaching task;

4) Actions and strategies: continuous reflection on the process of teacher training during the teaching exercise associated with the study of related themes from the comparative analysis of pedagogical plans and the conceptual maps built at different moments.

The plans were obtained in personal archives.

The thematic of the two conceptual maps were the same: Relation of Biochemistry with Animal Nutrition. This allowed to infer about the influence of the Biological Sciences Licenciatura undergraduate in the appropriation of specific knowledge. However, the first map was built in the first semester of 2015 during the third semester of Biology course and the second map was made two years after the first during the eighth period of the course in the second half of 2017 , with the aim of analyzing the teacher training through metacognition where the student himself makes a study of his own production in a reflexive and metacognitive action being both observer and object.

The first conceptual schema was hand-drawn on paper, but the second conceptual map was made in CMap Tools ${ }^{\circledR}$ a free conceptual mapping software. The non-use of software for the construction of the first conceptual map was due to the lack of knowledge of the tool and the option for its use in the second construction was due to the difficulty of materializing the conceptual map on paper due to the twodimensional limitation that did not include the size of the conceptual map.

It is important to highlight some nomenclatures used for the description of conceptual maps, such as the node, which is represented by conceptual text boxes that branch by lines to other nodes in a planned logical construction in a network system. The lines or links express direction of reading through arrows.
Due to the difficulty of reading the conceptual maps arranged in the normative structure of this paper they will be only described.

\section{Results and Discussion}

Through the application of specific knowledge, under the theme Biochemistry in Animal Nutrition, two Conceptual Maps were constructed that depict two distinct moments of initial training in Biological Sciences. The aim was to reflect on a theme used in teaching the discipline of Introduction to Animal Science in the Technical Vocational Course in Agriculture.

The initial reasoning for the construction of the maps was based on the concept of food that branched out to the nutrients that constitute it, possible toxic factors and their variations according to the influences of genetics and the environment (biotic and abiotic factors).

\subsection{First Discipline Plan}

Among the teacher evaluation categories proposed by Shulman [17]: (1) Organization of the preparation and presentation of the instructional plan; (2) evaluation; (3) recognition of individual differences; (4) cultural awareness; (5) understanding of youth; (6) management; (7) educational policies and procedures. For analysis of the first Discipline Plan, 2010, I will consider only the items "General Purpose", "Teaching Methodology" and "Evaluation" to meet the didacticpedagogical reflection. It is clear from the Teaching Methodology item that the class is centered on the exposition of theoretical information, a strong feature of traditional teaching. The stated objective is only the generalist, was not treated about the specific objectives of the discipline. Its vision is only that of Agribusiness, that is, only the intensive system of production, excluding the reality of the rural man and the alternative forms of production with lower environmental impact, greater sustainability and respect for the environment and social responsibility. The traditional or Newtonian-Cartesian paradigm led to the fragmentation of knowledge and the overvaluation of rational view, proposing the primacy of reason over emotion, where institutions are organized in watertight departments from which experts, considered holders, emerge. of knowing. The Cartesian view has reached the teaching pedagogical practice, where the student figures as a mere spectator who copies, memorizes and reproduces the contents, where his experience does not count.

In addition, the strong presence of the use of scientific articles in a high school level course is indicative of the strong link with the influence of bachelor technicist academic training. Not that you can't use this type of text in a high school course, but it should 
be very well designed according to the level of understanding of the class and appropriate to the level of education. These procedural gaps are first and foremost formative noticeable when we analyze what Shulman [17] expresses in understanding that content and process are necessary for 'professional teachers' and within content, one must include knowledge of the structures of a subject. , general pedagogical knowledge, domain specific topics and specialized curricular knowledge. Already Tardif [18] explains that the professional activity of professors should be considered as a practical space for the production, transformation and mobilization of knowledge and, consequently, theories, knowledge and know-how specific to the teacher's profession. This indicates that I lacked teacher training while vocational training. Despite presenting the possibility of using technical reports there is no concern with the issue of content contextualization. The country reality is specific in relation to the Zootechnics of other regions of Brazil, it is important to present other realities to confer a broad knowledge, but this knowledge must come from the local or regional reality. When considering the cognitive process of learning, when he states that the production of lasting changes is related to the fact that, by learning, there is a restructuring of knowledge and behaviors already existing in the learner. That is why a contextualized teaching is important.

The debates cited as methodology are centered only on the readings directed by the teacher, in order to be associated exclusively with the text or context explained in class and to encourage the participation and exchange of information and experiences among the students under the teacher's guidance. Learning is more likely to occur with meaning to the student, as action that transforms and shapes. In this point of view of social interaction.

The indication of practical classes and technical visits should be part of the technical disciplines enabling the know-how so required and valued in vocational technical education, but this know-how cannot be purely technical. It should allow the student to reflect in an interdisciplinary way. and complex visualizing several variables present in the know-how.

The same Cartesian influence is perceived in the forms of assessment, when the Sabbaths, reports of practical classes and technical visits, together with the test are much more than participation in class, giving the participation of the same student a very low importance. may not encourage student participation in class. In addition, exercise compliance is included as classroom participation in error. The test remains the center of the evaluation process with $60 \%$ equivalence. There is nothing related to attitudinal learning, that is, it will only be evaluated and, consequently, valued only conceptual knowledge.

\subsection{Second Discipline Plan}

In this recent Discipline Plan, it is possible to notice important changes, some imposed by the Discipline Plan model adopted at Campus Salgueiro, which is different from the one used at Campus Ouricuri, which allows, for example, to inform the amount of classes by content, but which, like the first document, has a failure to correlate classes with the semester dates according to the Academic Calendar, which would allow students to better follow the course planning according to the school days.

Objectives are arranged for each content allowing the Discipline Plan to be linked to the Lesson Plans and eliminating the generalist goal that becomes vague, just as it was in the first Discipline Plan. However, it is still based on content objectives, avoiding, for example, attitudinal learning objectives. The objectives of teaching are formative learning in conceptual, procedural and attitudinal, where the first requires the student to present a formative development in learning specific content, the second refers to the application of content. specific in everyday life is know-how, and the third, usually neglected by the traditional assessment model, should be concerned with promoting citizen and human formation by promoting learning about respect for differences, social inclusion, etc.

The adopted methodology already makes the class more flexible in the sense that there is an exposition of information with dialogue, presenting a concern with the students' participation in the teachinglearning process, favoring the construction of knowledge as they talk.

It is already possible to observe a greater departure from the traditional paradigmatic methodology, when it is exposed as the first evaluation a photographic exhibition of native caatinga animal species to perform zoological classification of these animals. It is an evaluation that promotes photography as a playful moment, involving and motivating, observing the surrounding environment and contextualizing the content. There is also a distribution of the content evaluation process which was not observed in the first Discipline Plan.

\subsection{First Lesson Plan}

As for the Lesson Plans, the first time I needed to use it was to provide the IF Sertão Pernambucano teacher exam, since I had qualified for the second stage, the Didactic Exam. The Lesson Plan I used was in according to a template provided by a Zootechnical class friend I had used when I was a monitor of the Animal Nutrition discipline. I made the substitutions of information and took the Lesson Plan to contest. I approached the Nutritional Management of Fish in the Didactic Evaluation of the event, but unfortunately, I don't have the file anymore. So, this was the model I 
used to build my first Teacher Lesson Plan at Ouricuri Campus (a school in Ouricuri, Pernambuco, Brazil).

The Class Plan in question presents an expository teaching strategy, as the Discipline Plan used for the same period, that learning is exclusively directed to the content and the evaluation of the class was through a short-written test, called Sabbath.

\subsection{Second Lesson Plan}

In the most recent lesson plan, it is possible to notice that the teacher identifies the class, the total number of students, which denotes a planning applied to the class. The objectives of the class are generally beyond, presenting the specifics and attitudinal objectives, that is the attitudes that the teacher wants to build in the student with the class. The methodology is richly described, including an indication of the planned time for each methodological step of teaching that is no longer centered on the use of presentation slides, but uses video, discussion of video, where possibly students' prior knowledge will emerge and then makes a dialogued exposition of the content.

The teaching strategies expose a methodology that uses photography that enables the use of cell phones to observe the caatinga animals, a biome present in the Brazilian semiarid, specifically in the city of Salgueiro where I work. It thus promotes a contextualized and dynamic teaching. The evaluation leaves the traditional profile and becomes procedural through an activity that goes beyond class and generates a product that is a Caatinga Fauna Photographic Exhibition in a local event, the IV Week of Farming.

The evolution of the Plans of Disciplines and the Plans of Plans consequently provided better classes, which also underwent improvement through the didactic and pedagogical knowledge from the Full Degree in Biological Sciences course, allowing the use of diversified teaching tools, playful and dynamic strategies. motivating students and enough teaching knowledge to teach and reflect on teaching practice, promoting constant teacher-student training.

The classes moved further away from the dependence of the Traditional Paradigm. They are increasingly contextualized and directed towards the human development of students in a holistic and nontechnical perspective.

Creativity for teaching is sharpened, teaching skills better developed, and the result is a good teaching performance in Integrated High School that no longer scares and has become the foundation of my performance. I currently use 3D models of a cow and a horse to teach the contents of Physiological Systems and Anatomy, as well as animal breed replicas to teach Ezoognosis and Racial and Productive Patterns.

Classes are not only focused on content, but also on the political and social issues that affect Brazilian semiarid producers. The use of the multimedia projector is simply ancillary, since the greater didactic-pedagogical security that I acquired allows seeing other means, other ways aiding cognitive and teaching flexibility.

\subsection{First Conceptual Map}

In the first conceptual map, the conceptual node "Nutrients" branches into Carbohydrates, Proteins, Lipids, Vitamins and Minerals and these are subdivided into their structural subcategories according to Molecular Biochemistry. The Nutrients converge to the node Metabolism that is constituted under the influence of the Environment, Genetics, the Physiological Stage and the Sex.

Metabolism is portrayed only as a physiological nutritional way consisting of Digestion and Absorption (variable in the digestive system of ruminants and non-ruminants). Absorption is due to the passage of the biochemical elements from the intestinal lumen to the circulatory system that distribute them to all tissues and cells, establishing the various metabolic pathways.

Genetics influence the Metabolism (represented by a link between the Genetics and Metabolism nodes) and the physiological stages through the variations between animal species and their breeds and zootechnical lines. The Physiological Stages branch out to the Maintenance and from that establish other Physiological Stages such as Gestation and Lactation, Reproduction, Growth and Fattening.

The Metabolic pathways are divided into Catabolism and Anabolism, where in the first biochemical reactions of energy consumption are established for the degradation of specific biomolecules such as proteolysis and lipolysis; anabolism represents the group of biochemical reactions that generate energy in the form of Adenosine Triphosphate (ATP) or certain biomolecules for production and tissue deposition.

\subsection{Second Conceptual Map}

The second conceptual map was organized in four parts or subareas according to the conceptual specificities, here called conceptual basic areas that structure a given branch. After identification and definition of the problem, the individual must draw a "mental map" of the elements, the relationships between them and the goals found for it, this internal representation allows to understand the problem and think about its solutions [1].

For the reading of the Conceptual Map, we will follow the numerical order of each area, starting from the great area of Animal Science (Biology applied to animal production) being represented by macroscopic components, such as the general foods present in 
nature that act on Animal Nutrition as the main node of area 2 that is specific to the area of Anatomy and Animal Physiology, this relates to the third large node, which is Molecular Biochemistry, which relates to biomolecules. Already in the microscopic field, present in the food and that undergo actions of the digestive metabolism, until following the area of number 4 that represents the great node of Systemic Biochemistry.

Area 1 relates to the central theme "Application of Biochemistry in Animal Nutrition" because of the livestock sector there is the production of carnivorous, omnivorous feed and also considers milk as the main food for young mammals and food sources of aquatic organisms' carnivores (mollusks, annelids, crustaceans and zooplankton), we can find the sectors of origin of animal feed.

Area 2, central region of orange color, has as main node Animal Nutrition, knowledge from the interaction of food and feed, anatomy and animal physiology of the digestive system responsible for digestion and absorption (in association with the circulatory system), which processes the food by breaking it into smaller and smaller particles. As each biomolecule (nutrient) has its molecular specificity and consequently a distinct metabolic process, Animal Nutrition implies in the interactional study between the two great areas of Biochemistry, Molecular and Systemic.

Area 3, the largest delimitation on the right on the map, is represented by Molecular Biochemistry as the main node, which deals with the study of Biomolecules (represented by nutrients and enzymes) from where biomolecular specifications such as proteins, carbohydrates, lipids, the vitamins and these branches out, each according to their classifications, so the proteins address the amino acids that divide into Non-Essential, Conditionally Essential, and Essential.

The lipids that form the fatty acids and this branch off into other lipid types such as saturated and unsaturated fatty acids of long, medium and short chain lengths (VVs) that have distinct physicochemical structures characterizing the cerides (wax animal, solid and semi-solid fats of animals and vegetable oils, cholesterol-based steroids, form steroid hormones and fat-soluble vitamins (A, D, E and $\mathrm{K})$, the cell membrane components phospholipids, eicosanoids which form a hormonal group composed of prostaglandins, leukotrienes (related to attack on foreign substances and consequent allergic process) and thromboxanes (acting on blood metabolism under pressure and coagulation).

Carbohydrates, like proteins, are organic polymers, formed by monosaccharides that bind from glycosidic bonds and make up a range of glycan molecules that follow from the basic monosaccharides aldoses (principal: glucose, galactose) and ketoses (fructose), forming disaccharides such as sucrose (glucose plus fructose) present in sugarcane, lactose (glucose plus galactose) milk sugar, and maltose (glucose plus glucose) as a result of starch digestion. Complex carbohydrates divided into insoluble or structural (represented by pectin, hemicellulose and cellulose components of the plant cell wall and fibrous food vegetable fiber) and soluble or energetic (those complex glycan biomolecules that serve as energy reserves for vegetables such as starch present in tubers and seeds) and glycogen (present in the muscles and liver of animals).

And vitamins that are subdivided into water soluble (vitamin C and complex B) and liposoluble (A, D, E and $\mathrm{K}$ ) and also act in the metabolic energy process so that carbohydrates are the first to be metabolized, followed by lipids, then the proteins can be catabolized and have their constituent amino acids serving as the energy base.

Carbohydrates and lipids are the main components of animal diet energy. The knowledge of the amino acids and their metabolic functions enabled the development of Precision Zootechnics in a specific area that is Amino acid Nutrition allowing the balancing of the diet according to the needs in amino acids. This has made possible higher production rates with earlier and more productive animals in quantity and quality, of course, that Nutrition represents only one of the factors for the productive increase of the animal.

Area 4 of the Conceptual Map, in yellow in the left region on the map, depicts the relationships of the great node of Systemic Biochemistry arising from the interaction of biomolecules in the physiology of the Digestive System and presents in several metabolic pathways, primarily distinguished in anabolism and catabolism. In addition to describing the respective catabolic and anabolic pathways, they cite the Electron Transfer Chain (CTE).

\subsection{Comparative Analysis of Conceptual Maps}

When comparing the first conceptual map with the second, it can be seen that the conceptual relations presented greater diversification in the second map and a decrease of the linear relations. Such conditions corroborate with the appropriation of a more integrated and complex thinking. One of the data that exemplifies this is the number of nodes in each conceptual map, the first is 72 nodes and the second map is made up of 154 nodes.

As for the areas in each map, three distinct areas can be identified in the constitution of the first map: the first having the food as the main node, the second having the nutrients as the main node and the third presenting the metabolism as the main node. The second map presents four distinct and well branched areas, except the central area of number 2 .

The first map does not consider the diversity of 
food or the areas of animal production, which is considered in the second map. Moreover, it presents linear and simplistic relations, it does not relate the physiological stages to the animal production. It does not make the feedback relationship of the production of ATP or catabolic pathways with the physiological stages of the animals, but although these contents of the systemic biochemistry are considered in the second map, there is no deepening being treated superficially.

The first map considers the difference of the digestive systems between ruminant and nonruminant animals, but does not extrapolate these differences to the food constitution, just as the first map does not make clear mention of the presence of vegetables in any of the areas, which is explained in the second map.

The production of the map in CMap Tools $®$ made it possible to describe the connections between nodes, facilitating the interpretation of the cognitive process, which was impaired in the first handmade map, which shows only the connections between the concepts.

\section{Conclusion}

The comparative analysis of the disciplines and lesson plans and the conceptual maps under the assumptions of metacognition according to Flavell [8], [9] and teacher training [17], [18] allowed us to point out that the undergraduate course specific to teacher training, called in Portuguese Licenciatura, had a great influence on the pedagogical skills and in the conceptual formation of applied biochemistry to Animal Nutrition for providing an evolution in the scope of systemic-complex thinking [2], a reflection on the specific content that developed with new conceptual constructions and the pedagogical knowledge and practices developed throughout the historical teacher.

Systemic-complex thinking can be verified in the relations to explain the plans and related this based on pedagogical knowledge with another intra and extrascholar context; and the expansion of conceptual relations in the construction of the second map, when the nodes increased, going from 72 to 154 and the increase of basic conceptual areas that involved the central theme. Consideration was given to many variables to think about and construct the theme.

During the comparative analysis it was possible to reflect on the maps and to perceive gaps, absence of relations through arrows between certain concepts in both the first and the second map. In fact, the reflection provided the exercise of a systemiccomplex thinking that allows us to each look at the changes in the analyzed maps.

Flavell's cognitive monitoring model could be applied as a metacognitive method for analyzing the student's intellectual and behavioral development during the course, as well as reflective teacher analysis, since the stages of the model were used as a personal analysis of cognitive knowledge through (1) consideration of personal variables (individual who studies to be a Biology teacher and already acts as a Animal Science teacher), task (compare disciplines and lessons plans and conceptual maps to analyse) and strategy (define a plan to perform the task); (2) the use of cognitive experiences, in this case represented by the conceptual maps themselves; (3) the objective of the metacognitive exercise was to monitor the development of didactic plans and too of the conceptual cognitive in Biochemistry throughout the course through the analysis of conceptual maps produced in two distinct moments, the beginning and the end of the course; (4) and the actions and strategies used that were based on teacher training, pedagogical skills applied, the conceptual specific knowledge and cognitive reflection.

Finally, the knowledge developed in expresses the historical and sociocultural moment of the author who changes according to time, gaining and losing concepts in the continuous process of construction and conceptual reconstruction [9] according to the training in Animal Science, the teaching practice as professor of Animal Science and teacher training in the undergraduate Biological Sciences.

\section{References}

[1] ALMEIDA, M.A. (2002). Estratégias metacognitiva: uma possibilidade no Ensino de Enfermagem. Revista Brasileira de Enfermagem, v. 55, n. 4, p. 424-429.

[2] BRAYNER-LOPES, F. M. (2015). Formação de docentes universitários: um complexo de interações paradigmáticas, 260f. Tese (Doutorado em Ensino das Ciências e matemática) - Universidade Federal Rural de Pernambuco, Recife.

[3] BRAZIL. (1996). Lei de Diretrizes e Bases da Educação Nacional, Lei $\mathrm{n}^{\circ}$. 9,394, de 20 de dezembro de 1996. Available in: <http://www.planalto.gov.br/ccivil_03/ LEIS/L9394.html>. Accessed in: 12 Dec. 2017.

[4] CYPEL, S. (2006). O papel das funções executivas nos transtornos da aprendizagem. In ROTTA, N.; OHLWEILE, L.; RIESGO, R. (Eds.), Transtornos da aprendizagem Abordagem neurobiológica e multidisciplinar, pp. 375-387, Porto Alegre: Artmed, 2006.

[5] DAVIS, C. (2005). Metacognição e sucesso escolar: articulando teoria e prática. Cadernos de Pesquisa, v. 35, n. 125,2005 , p. 205-230.

[6] FARIAS, P.L. 1999). Semiótica e cognição: os conceitos de hábito e mudança de hábito em C.S. Peirce. Revista Eletrônica Informação e Cognição, v. 1, n. 1, p. 12-16.

[7] FERNANDEZ, C. (2015). Revisitando a base de conhecimentos e o conhecimento pedagógico do conteúdo (PCK) de professores de Ciências. Revista Ensaio, v. 17, n. 2, p. 500-528. 
[8] FLAVELL, J.H. (1979). Metacognition and cognitive monitoring: a new area of cognitive - developmental inquiry. American Psychologist, v. 34, n. 10, p. 906-911.

[9] FLAVELL, J.H. (1976). Metacognitive aspects of problem solving. In: RESNICK, L.B. (Ed.). The nature of intelligence. Hillsdale, New Jersey: Lawrence Erlbaum Associates, p. 231-236.

[10] FORMOSINHO, J. A (2001) formação prática dos professores: da prática docente na instituição de formação à prática pedagógica nas escolas. Revista Portuguesa de Formação de Professores, v. 1, p. 37-54.

[11] GAUTHIER, C. (1998). Por uma teoria da Pedagogia: pesquisas contemporâneas sobre o saber docente. Ijuí: Unijuí.

[12] GRANGEAT, M. (1999). A metacognição, um apoio ao trabalho dos alunos. Porto: Porto.

[13] LIMA, A.C.A.; OLIVEIRA, B.C.S.A.; OLIVEIRA, E.L.; AZARIAS, J.S. (2016). Os saberes dos docentes e as contribuições das pesquisas de Tardif para se repensar o trabalho docente, a pedagogia e o ensino. Caderno de Educação, ano 19, v. 1, n. 48, p. 09-23.

[14] MARCON, D.; GRAÇA, A.B.S.; NASCIMENTO, J.V. (2010). Estruturantes da base de conhecimentos para o ensino de estudantes-professores de Educação Física. Motriz, v.16, n.3, p. 776-787.

[12] PARIS, S.; WINOGRAD, P. (1990). How metacognition can promote academic learning and instruction. Em B. JONES \& L. Idol (Orgs.), Dimensions of thinking and cognitive instruction. Hillsdale, N. J.: Erlbaum.

[13] SCOTT, L.M. (1994). Images in advertising: the need for a theory of visual rhetoric. Journal of Consumer Research, v. 21, p. 252-273.

[14] SHULMAN, L.S. (1987). Knowledge and teaching: foundations of the New Reform. Harvard Educational Review, v. 57, n.1, p. 1-23.

[15] TARDIF, M. (2000). Saberes profissionais dos professores e conhecimentos universitários - elementos para uma epistemologia da prática profissional dos professores e suas consequências em relação à formação para o magistério. Revista Brasileira de Educação, n. 13, p. 5-24.

[16] TARDIF, M.; RAYMOND, D. (2000). Saberes, tempo e aprendizagem do trabalho no magistério. Educação \& Sociedade, ano XXI, n. 73, p. 209-244.

[17] WOLFS, J. L. (2000). Análise das práticas educativas que visam à participação do aluno na avaliação diagnóstica, na condução e na regulação de suas aprendizagens. In: J. GRÉGOIRE et al. (org.), Avaliando as aprendizagens: os aportes da psicologia cognitiva. Porto Alegre, Editora Artes Médicas Sul, p. 169-179.

\section{Acknowledgment}

To the Federal Institute of Sertão Pernambucano, Campi Ouricuri and Salgueiro, for making my teaching schedule more flexible so that I could become a Professor of Biology and a doctorate in the Postgraduate Program in Science Teaching, both courses at the Federal Rural University of Pernambuco. 